\title{
Dipeptide-Based Metabolic Labeling of Bacterial Cells for Endogenous Antibody Recruitment
}

\author{
Jonathan M. Fura ${ }^{\S}$, Sean E. Pidgeon ${ }^{\S}$, Morgan Birabaharan, Marcos M. Pires ${ }^{*}$
}

Department of Chemistry, Lehigh University, Bethlehem, Pennsylvania 18015, United States

$\S$ These authors contributed equally.

* Corresponding authors. Email: map311@lehigh.edu

\section{Supporting Information}

APPENDIX

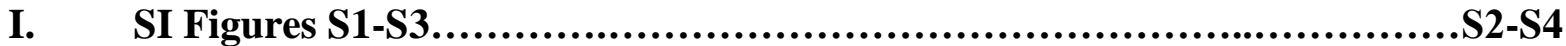

II. SI Synthetic Methods...................................................S5-S7

III. Compound Characterization.............................................S8-S13

IV. $\quad$ NMR Spectra of Compounds...........................................S14-S19 


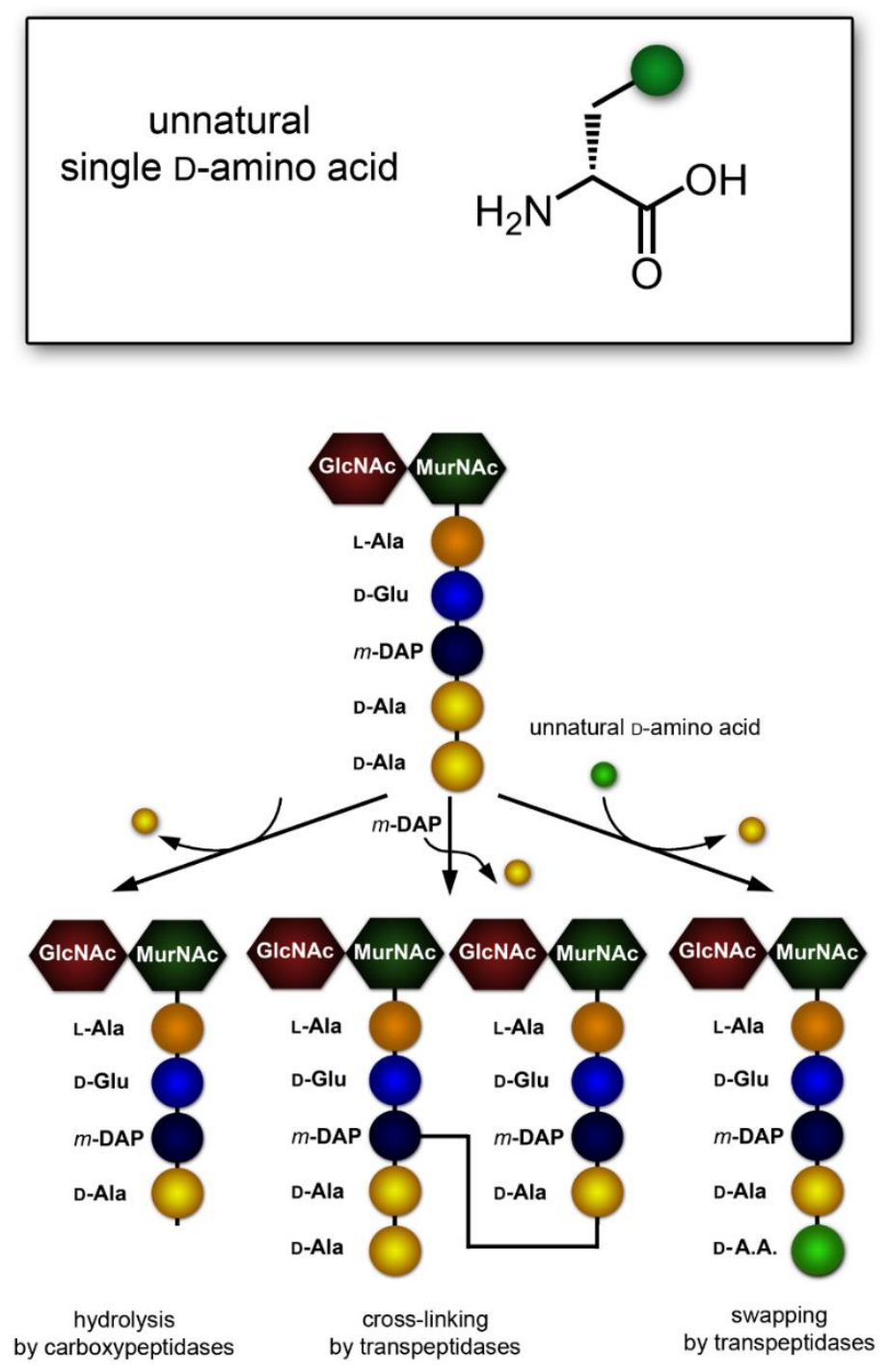

Figure S1. Schematic of peptidoglycan processing by PBPs. Terminal D-Ala residues are hydrolyzed at the C-terminus of the stem peptide by carboxypetidase (left). Adjacent oligopeptides are crosslinked by transpeptidase enzymes (middle). Exogenous D-amino acids are integrated into the stem peptide through transpeptidase mediated "swapping" of the terminal DAla (right). GlcNAc $=\mathrm{N}$-acetylglucosamine, MurNAc $=\mathrm{N}$-acetylmuramic acid, $m$-Dap $=$ mesodiaminopimelic acid. 

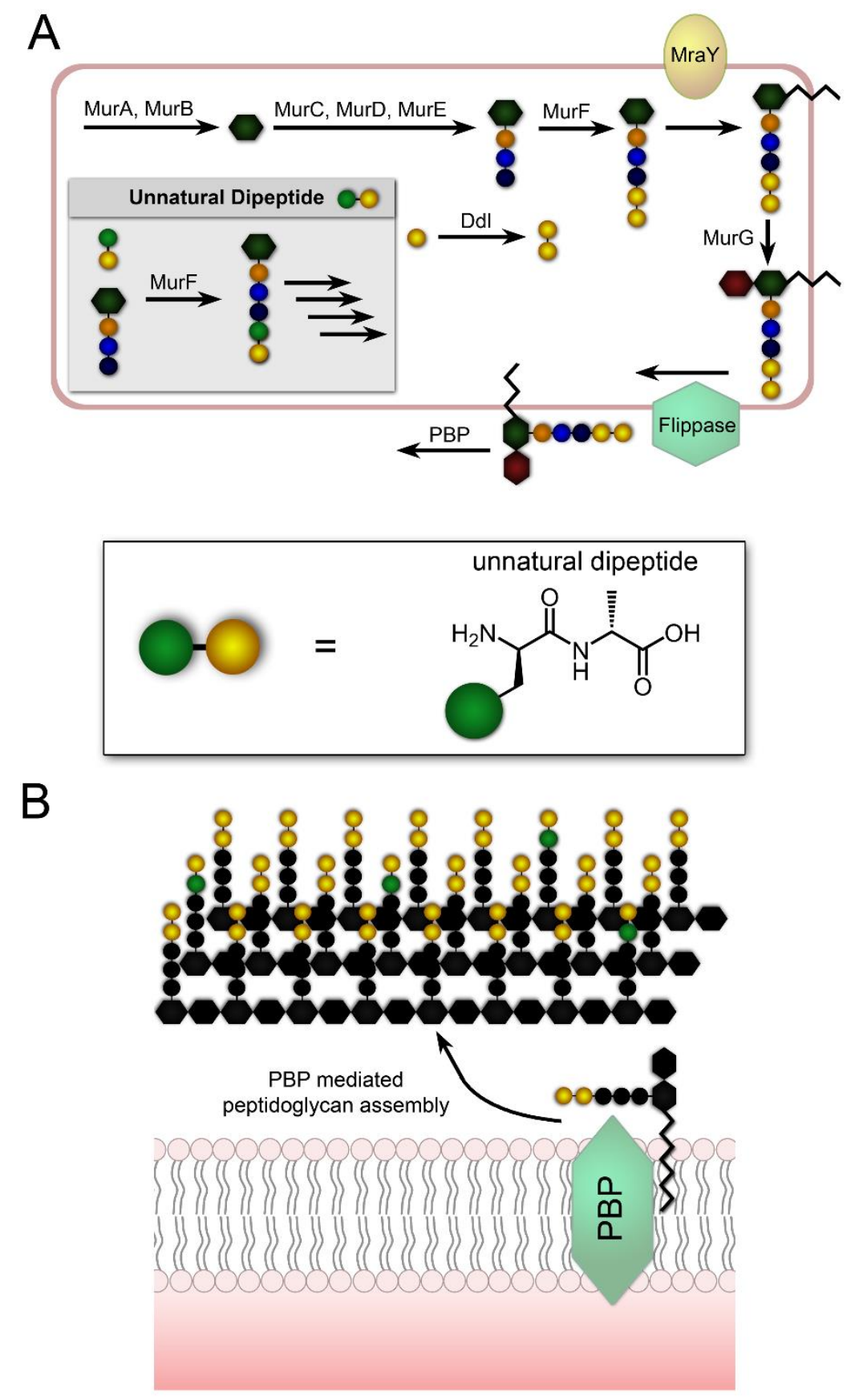

Figure S2. (A) Intracellular MurF promiscuity enables ligation of unnatural exogenous dipeptides into the growing stem peptide during peptidoglycan biosynthesis. (B) Unnatural dipeptide cell wall analogs are integrated into the growing peptidoglycan. Incorporation of chemically reactive handles facilitates site-selective modification of bacterial cell surfaces. 


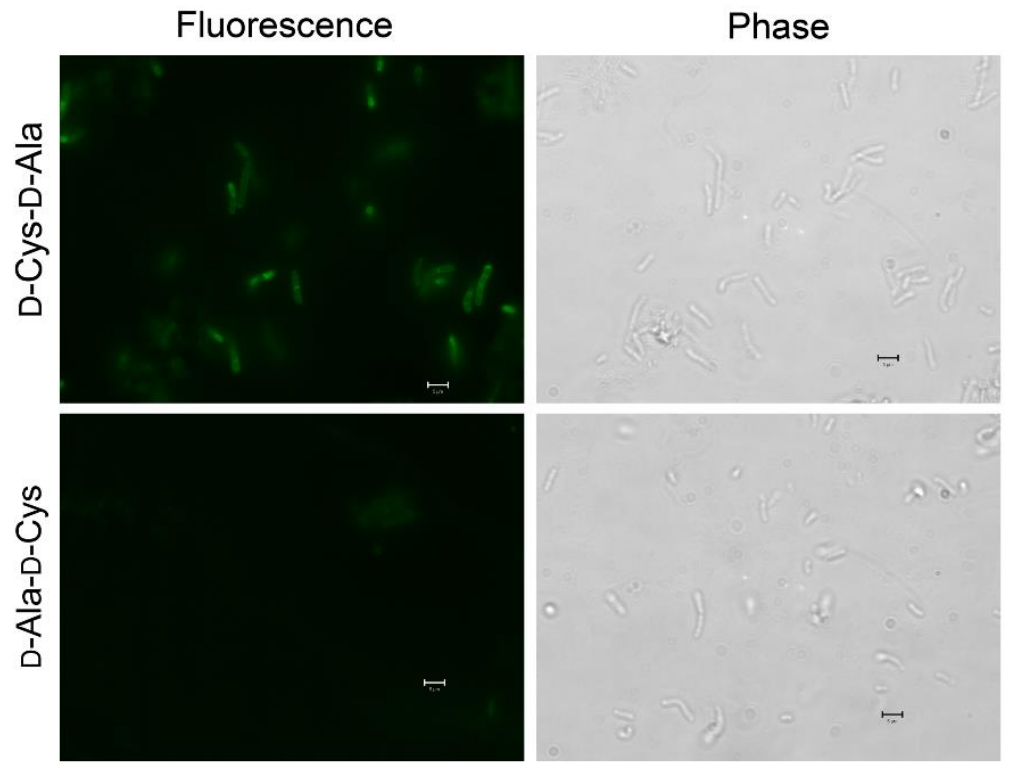

Figure S3. Phase and epifluorescent microscopy images. B. subtilis cells (wild type) were incubated overnight with $1 \mathrm{mM}$ of either D-Cys-D-Ala or D-Ala-D-Cys. Subsequently, cells were treated with $50 \mu \mathrm{M}$ of FL0 for $30 \mathrm{~min}$ and visualized using fluorescence microscopy. Scale bars $=5 \mu \mathrm{m}$. 
Materials. Reagents and Bacterial strains. Amino acids were purchased from Chem-Impex. Antibody reagents were purchased from Life-Technologies. All other organic reagents were purchased from Fisher Scientific and used without further purification. B. subtilis $\triangle d a c A$ and $B$. subtilis NCIB3610 were the strains of bacteria used for experiments.

General Synthesis of Sulfhydryl Dipeptides (solid phase). A 25ml synthetic flask was charged with $200 \mathrm{mg}(0.275 \mathrm{mmol})$ of 2-Chlorotrityl Chloride Resin. The resin was initially washed with dry $\mathrm{CH}_{2} \mathrm{Cl}_{2}(3 \times 5 \mathrm{ml})$ and dry DMF $(3 \times 5 \mathrm{ml})$. Initial loading was performed by the addition of Fmoc-protected amino acids (1 equiv, $0.275 \mathrm{mmol}$ ) in dry $\mathrm{CH}_{2} \mathrm{Cl}_{2}(5 \mathrm{ml})$ to the reaction flask with DIEA (4 equiv, $1.1 \mathrm{mmol}$ ) and the flask was agitated for 2 hours at room temperature. The resin was consequently washed with DMF, $\mathrm{CH}_{2} \mathrm{Cl}_{2}, \mathrm{MeOH}, \mathrm{CH}_{2} \mathrm{Cl}_{2}$ and DMF (3 x5 ml each). The Fmoc-protecting group was removed with a solution of $6 \mathrm{M}$ piperazine/100 $\mathrm{mM} \mathrm{HOBt}$ in DMF $(10 \mathrm{ml})$. The flask was agitated for $25 \mathrm{~min}$ and the deprotection solution was drained. The resin was washed with DMF, $\mathrm{CH}_{2} \mathrm{Cl}_{2}, \mathrm{MeOH}, \mathrm{CH}_{2} \mathrm{Cl}_{2}$, and DMF ( 2 x $5 \mathrm{ml}$ each). The addition of the second amino acid was performed by adding Fmoc-protected amino acids (4 equiv, 1.1 mmol), HBTU (4 equiv, $1.1 \mathrm{mmol}$ ), DIEA (8 equiv, $2.2 \mathrm{mmol}$ ) in DMF and agitating for two hours. Dipeptides were subsequently Fmoc-deprotected, washed as stated before and then cleaved using a TFA cocktail solution (82.5\% TFA, 2.5\% 1,2 ethanedithiol (EDT), 5\% thioanisole, $5 \% \mathrm{H}_{2} \mathrm{O}, 5 \%$ phenol). The resulting solutions were concentrated in vacuo to remove the TFA. The residue was triturated in cold diethyl ether and the precipitate was collected by centrifugation. Peptides were purified using reverse-phase high-performance liquid chromatography (RP-HPLC) using a Phenomenex C8 prep column with an eluent consisting of solvent $\mathrm{A}\left(\mathrm{H}_{2} \mathrm{O} / 0.1 \%\right.$ TFA $)$ and solvent $\mathrm{B}(\mathrm{MeOH} / 0.1 \%$ TFA) using a 60 min gradient transitioning from $5 \% \mathrm{~B}$ to $100 \% \mathrm{~B}$. The purity of the peptides were verified by analytical RPHPLC using a Phenomenex C4 column with an eluent consisting of solvent $\mathrm{A}\left(\mathrm{H}_{2} \mathrm{O} / 0.01 \%\right.$ TFA) and solvent $\mathrm{B}\left(\mathrm{CH}_{3} \mathrm{CN} / 0.01 \%\right.$ TFA) with a 30 min gradient transitioning from $5 \% \mathrm{~B}$ to $100 \% \mathrm{~B}$ at a flow rate of $3 \mathrm{ml} / \mathrm{min}$ and monitored at $220 \mathrm{~nm}$ and molecular weight was confirmed using electrospray ionization mass spectrometry.

General Synthesis of Fluorophore and Hapten Dipeptides (solid phase). A $25 \mathrm{ml}$ synthetic flask was charged with $200 \mathrm{mg}(0.275 \mathrm{mmol})$ of 2-Chlorotrityl Chloride Resin. The resin was initially washed with dry $\mathrm{CH}_{2} \mathrm{Cl}_{2}(3 \times 5 \mathrm{ml})$ and dry DMF $(3 \times 5 \mathrm{ml})$. Initial loading was performed by the adding a Fmoc-alanine protected amino acid (1 equiv, $0.275 \mathrm{mmol}$ ) in dry $\mathrm{CH}_{2} \mathrm{Cl}_{2}(5 \mathrm{ml}$ ) to the reaction flask with DIEA (4 equiv, $1.1 \mathrm{mmol}$ ) and agitating the flask for 2 hours at room temperature. The resin was consequently washed with $\mathrm{DMF}, \mathrm{CH}_{2} \mathrm{Cl}_{2}, \mathrm{MeOH}$, $\mathrm{CH}_{2} \mathrm{Cl}_{2}$ and DMF ( $3 \times 5 \mathrm{ml}$ each). The Fmoc protecting group was removed with a solution of 6 M piperazine/100 mM HOBt in DMF $(10 \mathrm{ml})$. The flask was agitated for $25 \mathrm{~min}$ and the deprotection solution was drained. The resin was washed with DMF, $\mathrm{CH}_{2} \mathrm{Cl}_{2}, \mathrm{MeOH}, \mathrm{CH}_{2} \mathrm{Cl}_{2}$, and DMF $\left(2 \times 5 \mathrm{ml}\right.$ each). For dipeptides modified with NBD or DNP, either a $\mathrm{N}^{\alpha}$-Boc- $\mathrm{N}^{\varepsilon}$ Fmoc-D-Lysine or a $\mathrm{N}^{\alpha}$-Boc- $\mathrm{N}^{\varepsilon}$-Fmoc-D-2,3 diaminopropionic acid was added to the resin. 
Upon addition, the Fmoc-protecting group was removed as stated before. Following washing of the resin, either 4-Chloro-7-nitro-1,2,3-benzoxadiazole (NBD-Chloride) (5 equiv, $1.38 \mathrm{mmol}$ ) and DIEA (7.5 equiv, $2.06 \mathrm{mmol}$ ) in DMF (10 ml) or 1-fluoro-2,4 dinitrobenze (DNFB) (5 equiv, $1.38 \mathrm{mmol})$ and DIEA ( 7.5 equiv, $2.06 \mathrm{mmol})$ in DMF $(10 \mathrm{ml})$ was added to the flask and was agitated for $1 \mathrm{~h}$ at room temperature protected from light was added to the flask and agitated for $1 \mathrm{~h}$ at room temperature protected from light for NBD-conjugated dipeptides. The resin was drained and subsequently washed with DMF, $\mathrm{CH}_{2} \mathrm{Cl}_{2}, \mathrm{MeOH}, \mathrm{CH}_{2} \mathrm{Cl}_{2}$, DMF (3 x $5 \mathrm{ml}$ each). For cleavage of the dipeptides and amino acid compounds not containing a cysteine residue from the resin, a trifluoroacetic acid (TFA) cocktail solution (95\%, 2.5\% triisopropylsilane (TIPS), $2.5 \%$ $\mathrm{H}_{2} \mathrm{O}$ ) was added to the resin and agitated for $1 \mathrm{~h}$ at room temperature protected from light. The resulting solutions were concentrated in vacuo to remove the TFA. The residue was triturated in cold diethyl ether and the precipitate was collected by centrifugation. Peptides were purified using reverse-phase high-performance liquid chromatography (RP-HPLC) using a Phenomenex $\mathrm{C} 8$ prep column with an eluent consisting of solvent $\mathrm{A}\left(\mathrm{H}_{2} \mathrm{O} / 0.1 \%\right.$ TFA) and solvent $\mathrm{B}(\mathrm{MeOH}$ $/ 0.1 \%$ TFA) using a $60 \mathrm{~min}$ gradient transitioning from $5 \% \mathrm{~B}$ to $100 \% \mathrm{~B}$. The purity of the peptides were verified by analytical RP-HPLC using a Phenomenex C4 column with an eluent consisting of solvent $\mathrm{A}\left(\mathrm{H}_{2} \mathrm{O} / 0.01 \%\right.$ TFA $)$ and solvent $\mathrm{B}\left(\mathrm{CH}_{3} \mathrm{CN} / 0.01 \%\right.$ TFA $)$ with a $30 \mathrm{~min}$ gradient transitioning from $5 \% \mathrm{~B}$ to $100 \% \mathrm{~B}$ at a flow rate of $3 \mathrm{ml} / \mathrm{min}$ and monitored at $220 \mathrm{~nm}$ and molecular weight was confirmed using electrospray ionization mass spectrometry.

\section{General Synthesis for Fluorescent-Maleimide-Linkers and Antigen-Maleimide-Linkers} (solid phase). A $25 \mathrm{ml}$ synthetic flask was charged with $250 \mathrm{mg}(0.12 \mathrm{mmol})$ of Rink Amide Resin. The resin was initially washed with DMF $(3 \times 5 \mathrm{ml})$ and deprotected with $6 \mathrm{M}$ piperazine/100 $\mathrm{mM}$ HOBT. The flask was agitated for $25 \mathrm{~min}$ and the deprotection solution was drained. The resin was washed with DMF, $\mathrm{CH}_{2} \mathrm{Cl}_{2}, \mathrm{MeOH}, \mathrm{CH}_{2} \mathrm{Cl}_{2}$, and DMF ( 2 x $5 \mathrm{ml}$ each). Initial loading was performed by the addition of $\mathrm{N}^{\alpha}$-Fmoc- $\mathrm{N}^{\varepsilon}$-methyltrityl-L-Lysine( 3 equiv, $0.36 \mathrm{mmol}$ ), HBTU (3 equiv, $0.36 \mathrm{mmol}$ ), and DIEA(6 equiv, $0.72 \mathrm{mmol}$ ) in DMF to the reaction flask and was agitated for 2 hours at room temperature. Addition of Fmoc-protected amino acids was carried out using the afore mentioned protocol to produce linker molecules constituted of Gly-Gly-Ser amino acid repeating units of differing length. Once the desired linker length was achieved, the Fmoc-protecting group of the terminal glycine was then removed with $6 \mathrm{M}$ piperazine $/ 100 \mathrm{mM} \mathrm{HOBt}$ solution by agitating the flask for 25 minutes. The protecting solution was then drained and the resin was washed with DMF, $\mathrm{CH}_{2} \mathrm{Cl}_{2}, \mathrm{MeOH}, \mathrm{CH}_{2} \mathrm{Cl}_{2}$, and DMF ( 2 x $5 \mathrm{ml}$ each). Subsequently, NBD-Chloride or DNFB, ( 5 equiv, $0.60 \mathrm{mmol}$ ) with DIEA (7.5 equiv $0.90 \mathrm{mmol}$ ) in DMF was added to the resin and agitated for 1 hour protected from light to conjugate the either the NBD fluorophore or DNP antigen. Following addition of the fluorophore or hapten, the solution was drained and washed as stated before. The $\mathrm{N}^{\varepsilon}$-methyltrityl protecting group of the lysine was then deprotected by adding a 10mls of a TFA cocktail solution (1\% TFA, 2\% TIPS in $\mathrm{CH}_{2} \mathrm{Cl}_{2}$ ) to the resin and agitating for 10 mins protected from light. The 
solution was drained and this procedure was repeated four additional times. The solution was then drained and washed as previously stated. Upon MTT deprotection, 3-maleimidopropionic acid ( 3 equiv, $0.36 \mathrm{mmol}$ ), HBTU (0.36 equiv, $0.36 \mathrm{mmol}$ ), and DIEA (6 equiv, $0.72 \mathrm{mmol}$ ) in DMF was added to the resin. The peptides were cleaved by adding a trifluoroacetic acid (TFA) cocktail solution (95\%, TFA, 2.5\% TIPS, and $2.5 \% \mathrm{H}_{2} \mathrm{O}$ ) to the resin and the mixture was agitated for $1 \mathrm{~h}$ at room temperature protected from light. The resulting solution was concentrated in vacuo to remove the TFA. The residue was triturated in cold diethyl ether and the precipitate was collected by centrifugation. Peptides were purified using reverse-phase highperformance liquid chromatography (RP-HPLC) using a Phenomenex C8 prep column with an eluent consisting of solvent $\mathrm{A}\left(\mathrm{H}_{2} \mathrm{O} / 0.1 \%\right.$ TFA) and solvent $\mathrm{B}(\mathrm{MeOH} / 0.1 \%$ TFA) using a 60 min gradient transitioning from $5 \% \mathrm{~B}$ to $100 \% \mathrm{~B}$. The purity of the peptides were verified by analytical RP-HPLC using a Phenomenex C4 column with an eluent consisting of solvent A $\left(\mathrm{H}_{2} \mathrm{O} / 0.01 \%\right.$ TFA) and solvent $\mathrm{B}\left(\mathrm{CH}_{3} \mathrm{CN} / 0.01 \%\right.$ TFA $)$ with a 30 min gradient transitioning from $5 \% \mathrm{~B}$ to $100 \% \mathrm{~B}$ at a flow rate of $3 \mathrm{ml} / \mathrm{min}$ and monitored at $220 \mathrm{~nm}$ and molecular weight was confirmed using matrix-assisted laser desorption ionization time-of-flight (MALDI-TOF) mass spectrometry. 


\section{Compound Characterization}

\section{Compound 1:}<smiles>N[C@@H](CCCCNc1ccc([N+](=O)[O-])c2nonc12)C(=O)O</smiles>

MS (ESI) [M+H'] 310.3 (calculated), 310.3 (found)

\section{Compound 2:}<smiles>C[C@H](NC(=O)[C@H](N)CNc1ccc([N+](=O)[O-])c2nonc12)C(=O)O</smiles>

MS (ESI) $\left[\mathrm{M}+\mathrm{H}^{+}\right]$: 339.3(calculated), 339.4 (found)

\section{Compound 3:}<smiles>C[C@H](NC(=O)[C@H](N)CCCCNc1ccc([N+](=O)[O-])c2nonc12)C(=O)O</smiles>

MS (ESI) [M+H'] : 381.4(calculated), 381.2 (found) 


\section{Compound 4}<smiles>C[C@H](NC(=O)[C@H](N)CS)C(=O)O</smiles>

MS (ESI) [M+H'] 193.3 (calculated), 193.3 (found)

Compound 5<smiles>C[C@H](N)C(=O)N[C@@H](CS)C(=O)O</smiles>

MS (ESI) [M+H']: 193.3 (calculated), 193.3 (found)

Compound 6: Purchased from Chemlmpex and used without any further synthesis or purification.

\section{Compound 7}<smiles>C[C@H](NC(=O)[C@H](N)CS)C(=O)O</smiles>

MS (ESI) $\left[\mathrm{M}+\mathrm{H}^{+}\right]: 193.3$ (calculated), 193.3 (found)

Compound 8<smiles>C[C@H](NC(=O)[C@H](N)CS)C(=O)O</smiles>

MS (ESI) [M+H']: 193.3 (calculated), 193.3 (found) 


\section{Compound FLO}<smiles>NC(=O)C(CCCCNC(=O)CCN1C(=O)C=CC1=O)Nc1ccc([N+](=O)[O-])c2nonc12</smiles>

MS (ESI) [M+H']: 460.2 (calculated), 460.2 (found)

\section{Compound FL1}

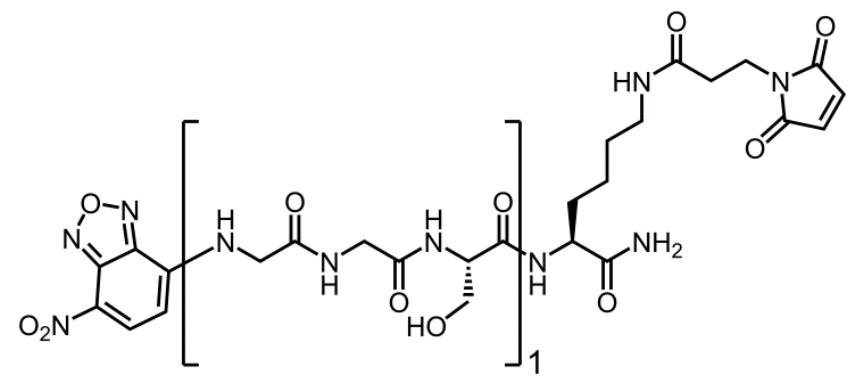

MALDI-TOF [M+Na+]: 683.6 (calculated), 683.5 (found)

\section{Compound FL2}

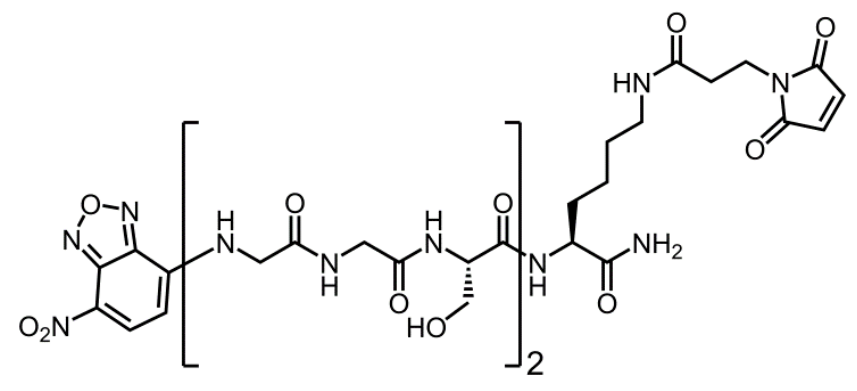

MALDI-TOF [M+Na+]: 886.8 (calculated), 886.5 (found) 


\section{Compound FL3}

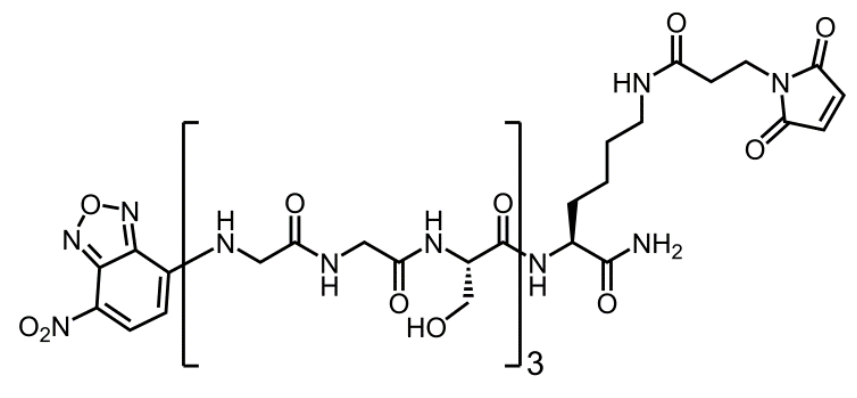

MALDI-TOF $\left[\mathrm{M}+\mathrm{Na}^{+}\right]$: 1086.0 (calculated), 1086.4 (found)

\section{Compound FL4}

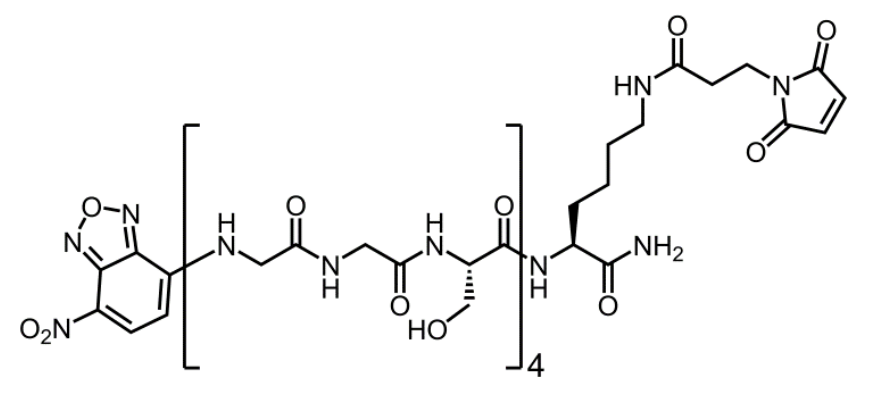

MALDI-TOF [M+Na $]$ : 1287.2 (calculated), 1287.1 (found)

\section{Compound DLO}<smiles>NC(=O)[C@H](CCCCNC(=O)CCN1C(=O)C=CC1=O)Nc1ccc([N+](=O)[O-])c2nonc12</smiles>

MS (ESI) $\left[\mathrm{M}+\mathrm{H}^{+}\right]$: 463.4 (calculated), 463.2 (found) 


\section{Compound DL1}

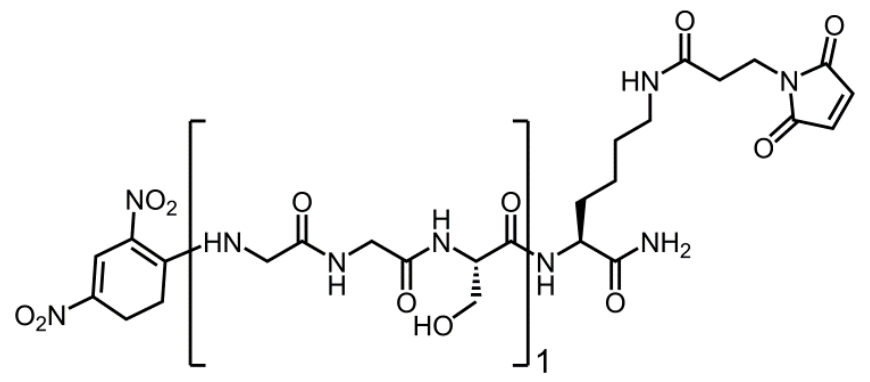

MALDI-TOF [M+Na $\left.{ }^{+}\right]: 686.6$ (calculated), 686.7 (found)

\section{Compound DL2}

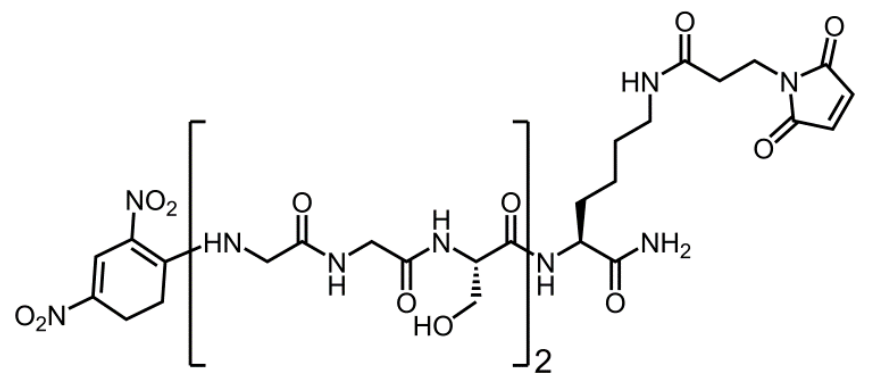

MALDI-TOF $\left[\mathrm{M}+\mathrm{H}^{+}\right]: 887.8$ (calculated), 887.7 (found)

\section{Compound DL3}

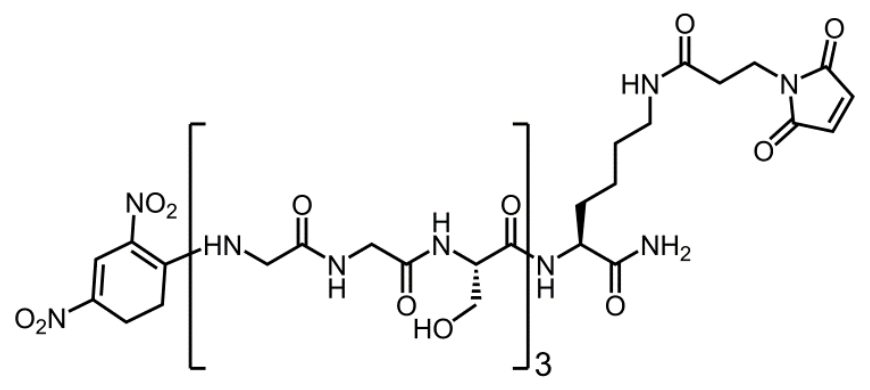

MALDI-TOF $\left[\mathrm{M}+\mathrm{Na}^{+}\right]$: 1089.0 (calculated), 1088.4 (found) 


\section{Compound DL4}

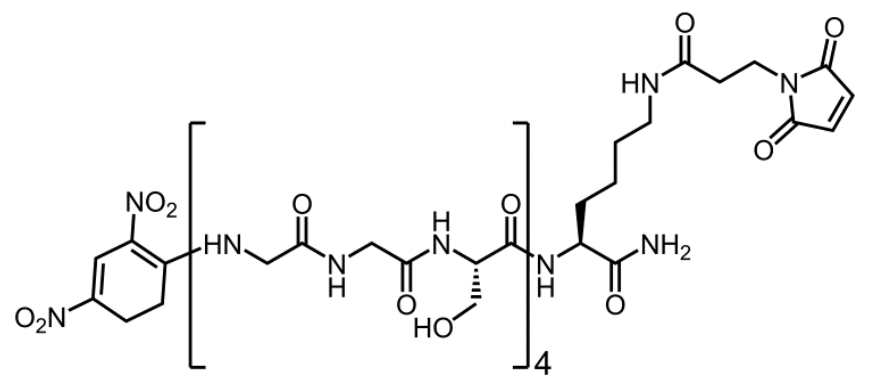

MALDI-TOF [M+Na+]: 1290.1(calculated), 1290.3(found)

\section{Compound DL5}

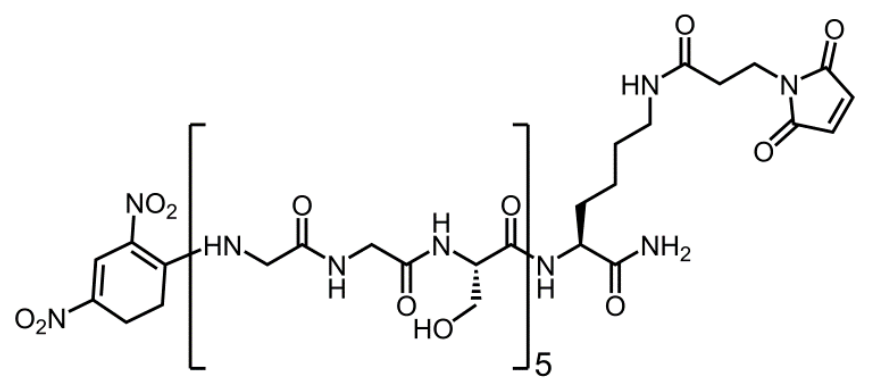

MALDI-TOF [M+Na+]: 1491.3 (calculated), 1489.0 (found) 


\section{Compound 2: 1H-NMR}

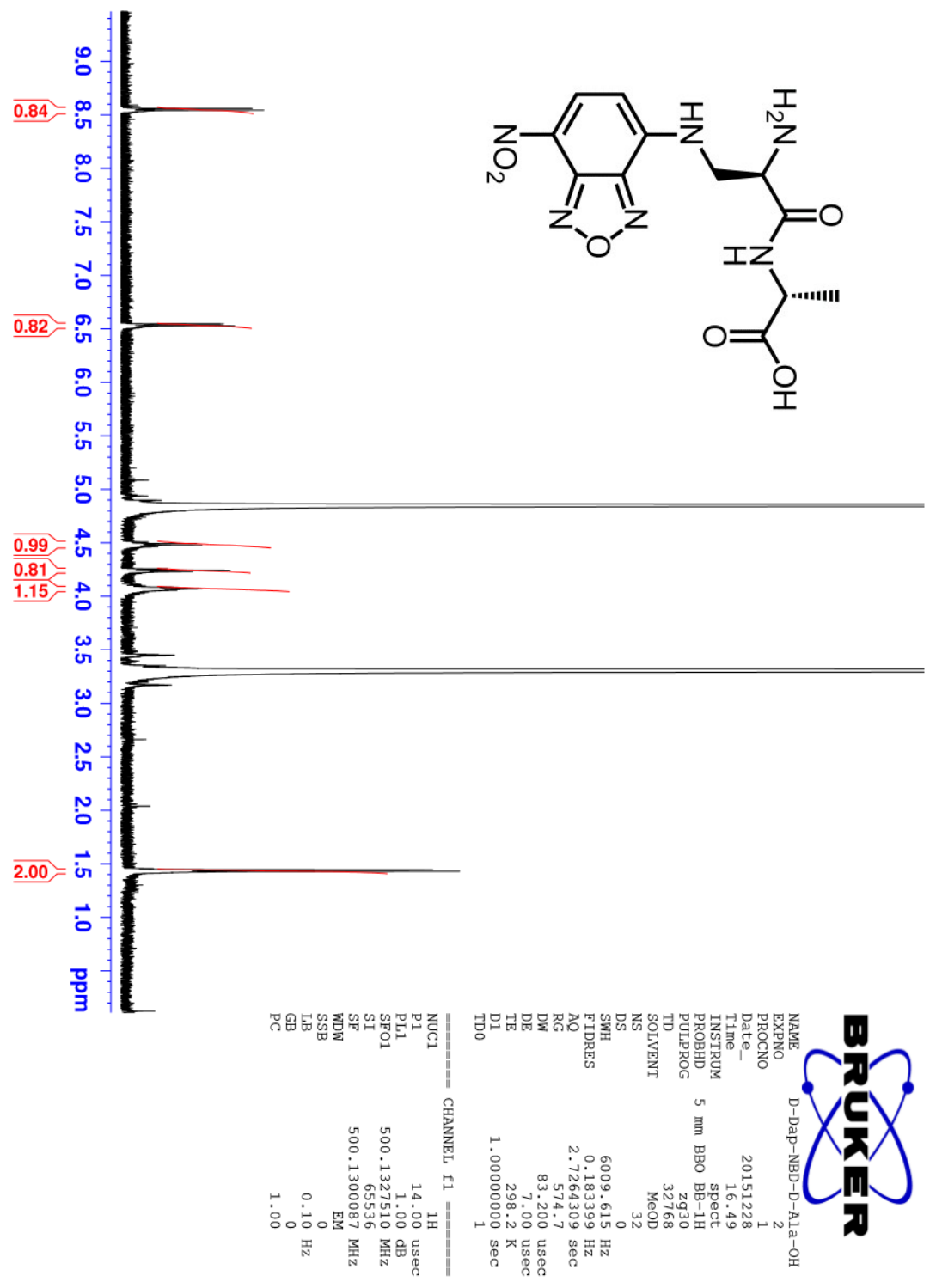




\section{Compound 2: 13C-NMR}

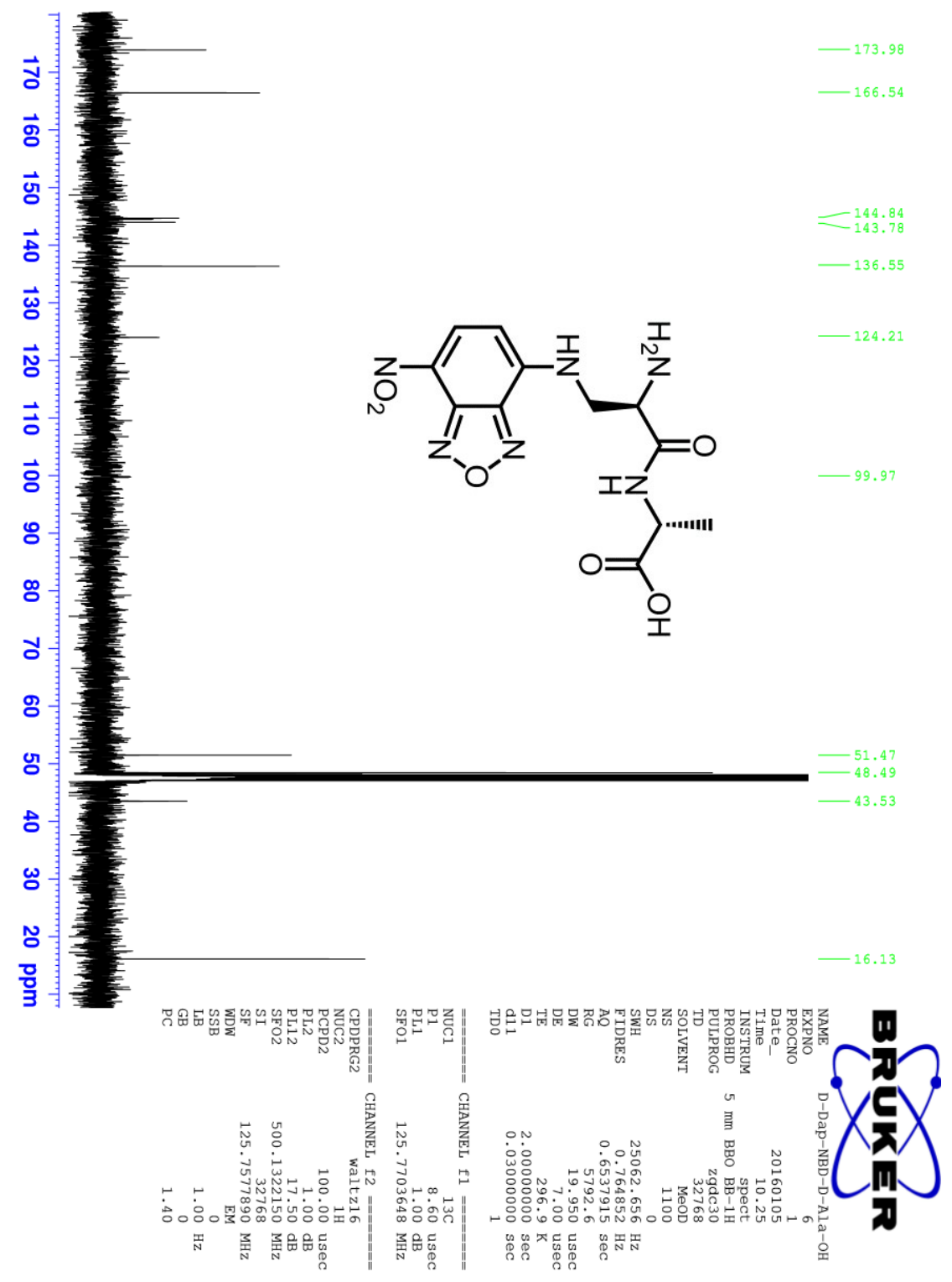




\section{Compound 3: 1H-NMR}

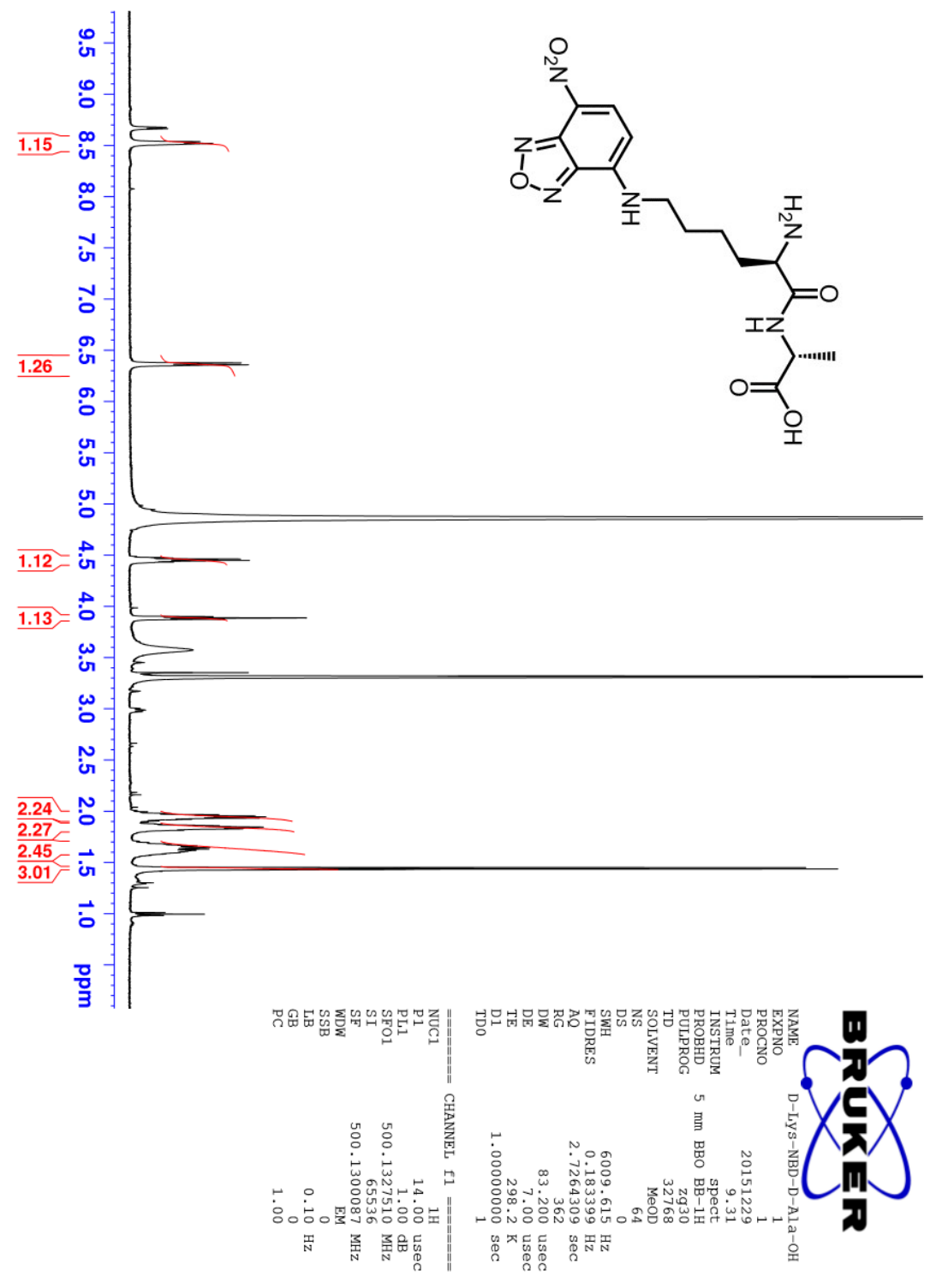


Compound 3: 13C-NMR

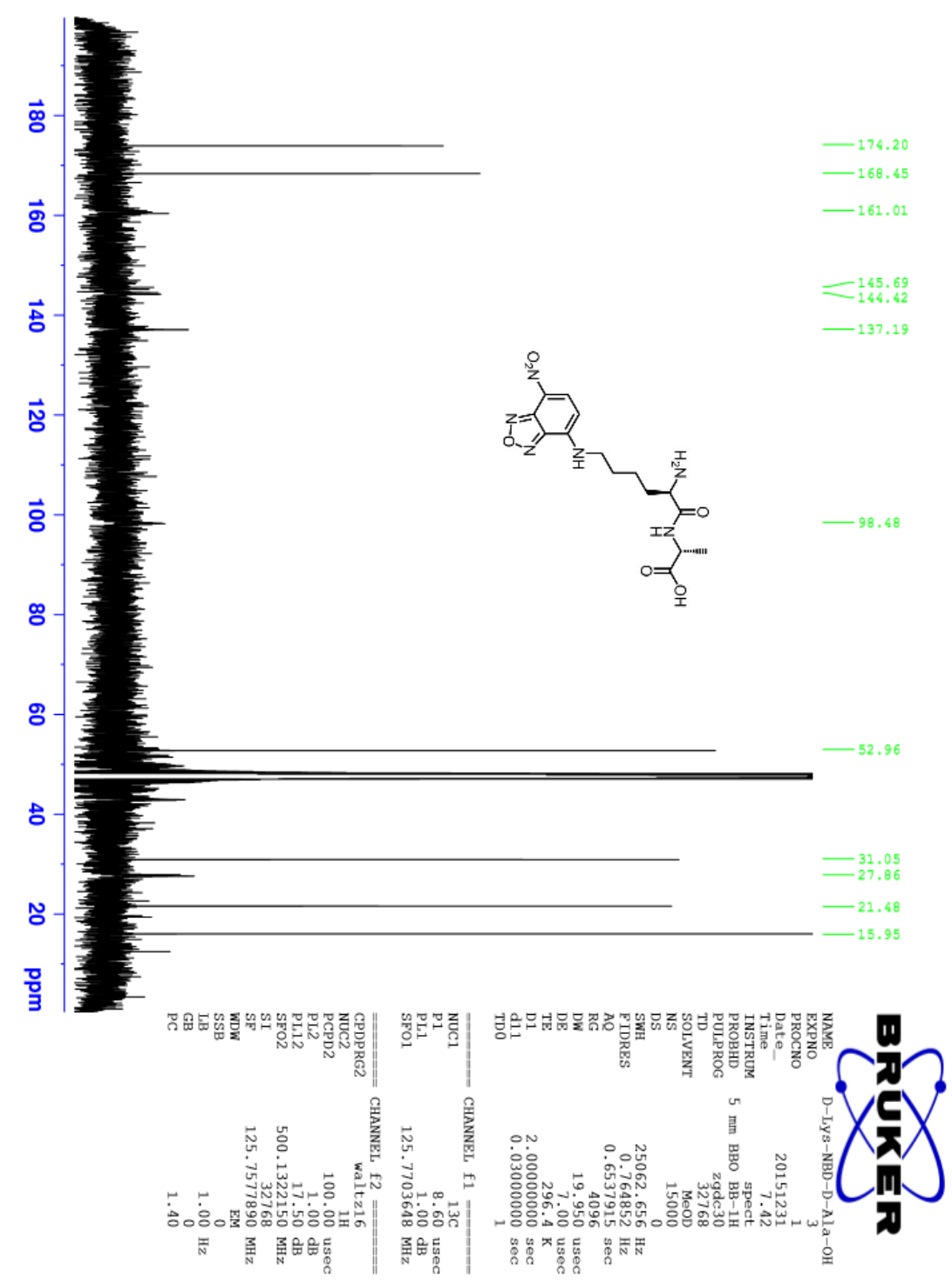




\section{Compound 4: 1H-NMR}

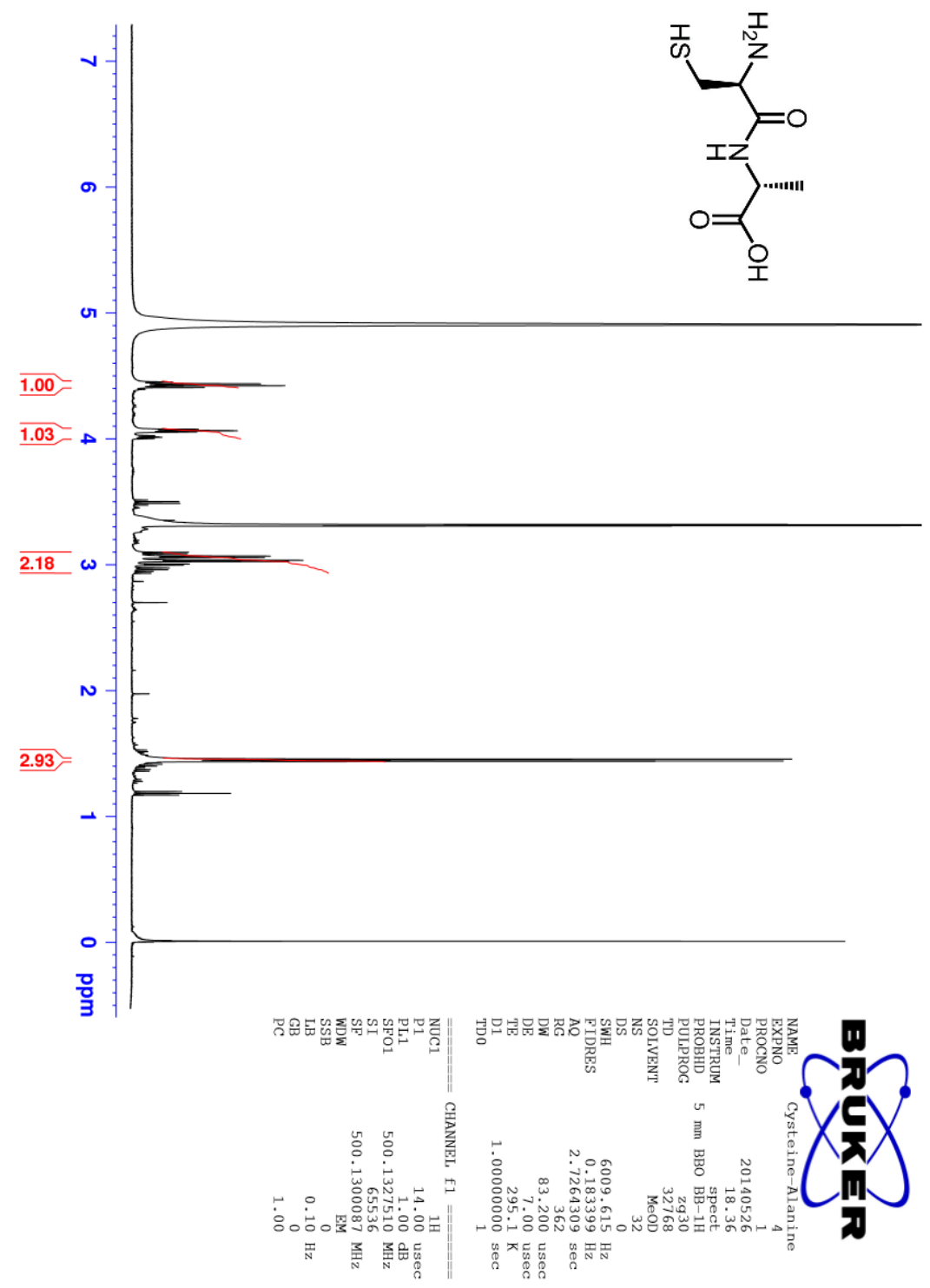




\section{Compound 4: 13C-NMR}

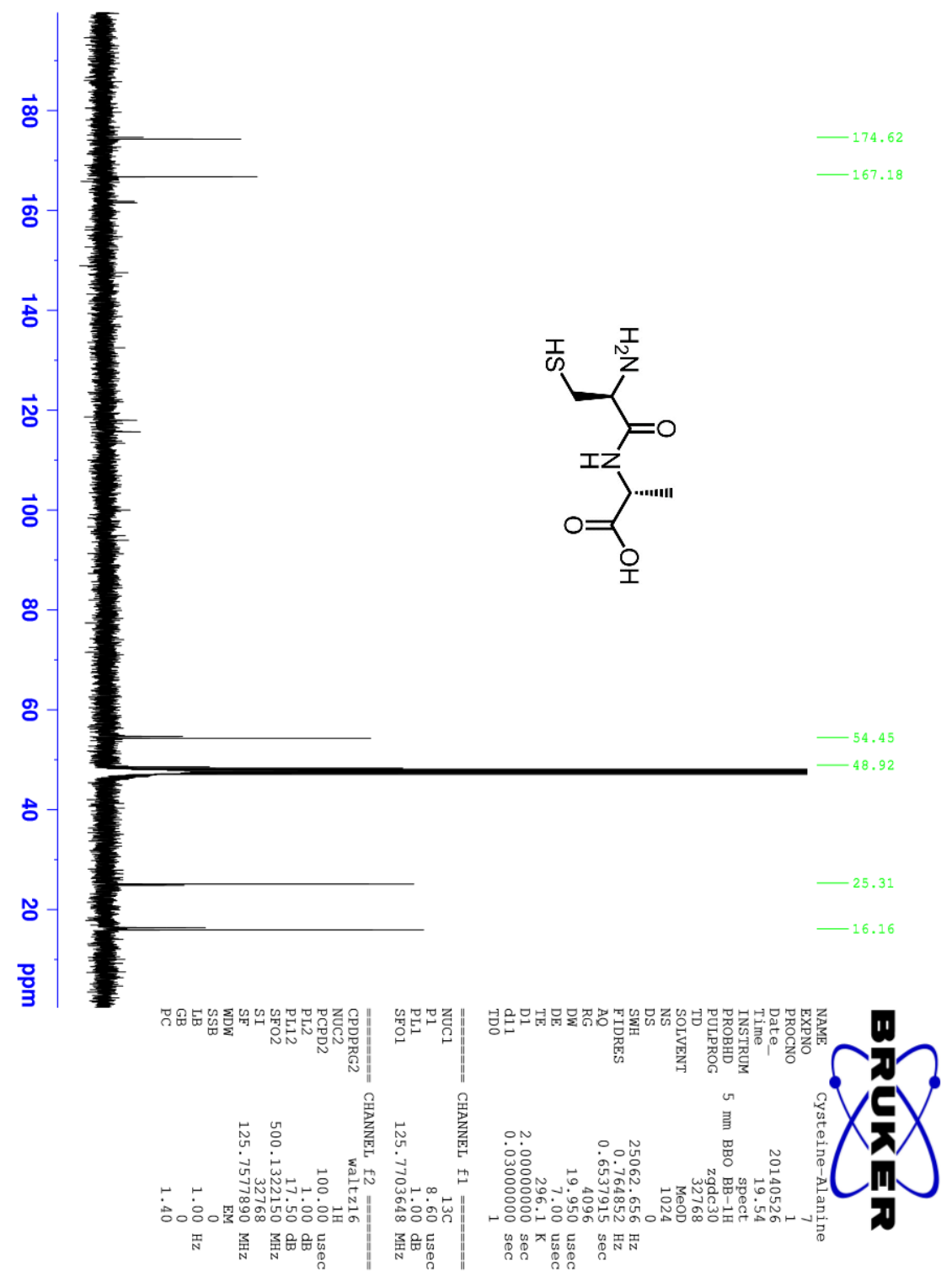

